\title{
Evaluation of Gladiolus Genotypes for Resistance to Different Isolates of Fusarium oxysporum f. sp. gladioli
}

\author{
Raimani Hembrom ${ }^{1}$, T. Manjunatha Rao $^{2}$, S. Sriram ${ }^{3}$, Rajiv Kumar ${ }^{2}$, \\ R. Venugopalan ${ }^{4}$ and M.V. Dhananjaya ${ }^{2}$
}

${ }^{I}$ Department of Horticulture, RAC, BAU, Ranchi-834 006, India

${ }^{2}$ Division of Floriculture \& Medicinal crops, ICAR-IIHR, Bengaluru- 560089

(ISO 9001:2008 Institute), India

${ }^{3}$ Division of Plant Pathology, ICAR-IIHR, Bengaluru- 560089

(ISO 9001:2008 Institute), India

${ }^{4}$ Statistics Laboratory, ICAR-IIHR, Bengaluru- 560089 (ISO 9001:2008 Institute), India

*Corresponding author

\section{A B S T R A C T}

\begin{tabular}{|l|}
\hline Ke y w or d s \\
$\begin{array}{l}\text { Disease incidence, } \\
\text { Fusarium } \\
\text { oxysporum f. sp. } \\
\text { gladioli, Gladiolus, } \\
\text { Resistance, SAS, } \\
\text { Wilt }\end{array}$ \\
\hline Article Info \\
\hline $\begin{array}{l}\text { Accepted: } \\
\text { 20 May } 2019 \\
\text { Available Online: } \\
\text { 10 June } 2019\end{array}$ \\
\hline \hline
\end{tabular}

\section{Keywords}

oxysporum f. sp. gladioli, Gladiolus Resistance, SAS, Wilt

Accepted:

Available Online

10 June 2019
A study was conducted with nine gladiolus genotypes namely Arka Aayush, Arka Amar, Arka Darshan, Arka Gold, Arka Kumkum, Pink Friendship, IIHRG-12, Gladiolus callianthus and Psittacinus hybrid for resistance against two geographically different isolates of Fusarium oxysporum f. sp. gladioli (FOG) i.e. FGS-SOL isolate and FOG IIHR-1 isolate. Pink Friendship recorded highest disease incidence $(91.67 \%)$ which was inoculated by FOG IIHR-1 isolate whereas no disease incidence was observed in inoculated plants of Psittacinus hybrid. The dendrogram deduced from various characters showed high similarity between Arka Aayush and Arka Darshan in FGS-SOL isolate inoculation and between Arka Amar and Arka Kumkum in FOG IIHR-1 isolate inoculation. Disease progress was measured through area under disease progression curve (AUDPC) and highest AUDPC value was recorded in Pink Friendship inoculated with FOG IIHR-1 isolate. Genotypes Arka Amar, Pink Friendship and IIHRG-12 took minimum days to sprouting, spike emergence and opening of $1^{\text {st }}$ floret, respectively. Gladiolus callianthus exhibited maximum plant height and spike length. Number of corms per corm was highest in Psittacinus hybrid. Arka Gold recorded maximum average weight of corm and diameter of corm. Resistant genotypes which were identified can be used in breeding programs for development of resistant cultivars.

\section{Introduction}

Gladiolus (Gladiolus hybridus Hort.) is a bulbous cut flower which belongs to the family Iridaceae and sub-family Ixioideae (Manning and Goldblatt, 2008). This genus contains 300 species which are widely distributed across Southern Africa, Mediterranean region and Eurasia (Cantor and Tolety, 2011). The inflorescence of gladiolus known as spike comprises of funnel shaped individual flowers called floret. Gladiolus is 
commercially propagated through underground modified stem known as corms and cormels. It is known to have an excellent vase life and is considered as an economically important flower crop in India. It is commercially cultivated in West Bengal, Karnataka, Tamil Nadu, Maharashtra, Madhya Pradesh, Punjab, Haryana, Uttar Pradesh, Uttarakhand and Himachal Pradesh. It ranks second in area (20.53 ' 000 ha) and production (132.58 '000 tons) among the cut flowers grown in India (Anonymous, 2016). Gladiolus is widely used in bouquet, flower arrangements, borders and bedding purposes (Dwivedi et al., 2018).

Fusarium wilt is the most devastating disease in gladiolus which is caused by the fungus Fusarium oxysporum Schltdl. f. sp. gladioli (Massey) W.C. Snyder \& H.N. Hansen (Massey, 1926 and Nelson et al., 1981). It is a major bottleneck in gladiolus cultivation causing 60-80 \% crop damage and huge economic loss to flower growers (Lakshman et al., 2012 and Kakade et al., 2016). The infected plants show symptoms of yellowing, bending of spikes, inability to bloom, production of small sized florets, drying and eventual death of plants. Fusarium corm rot can be observed both in field and during storage (Riaz et al., 2010). The infected corms in storage develop brown to black lesions and eventually become mummified. Conventional management practices for Fusarium wilt disease include corm treatment with fungicides and soil fumigation. These measures are time consuming and labour intensive which also increase the cost of cultivation. Disease resistance is considered as a sustainable method for disease management which is eco-friendly and economically viable (Mundt, 2014). Identification of genetic resources for resistance to Fusarium wilt is crucial for harnessing resistance from these plants which can be deployed in development of resistant varieties. The present study is concerned with the resistance response of different gladiolus genotypes to two geographically different isolates of F. oxysporum f. sp. gladioli (FOG).

\section{Materials and Methods}

\section{Plant material}

Uniform, healthy and disease-free corms of nine gladiolus genotypes viz., Arka Aayush, Arka Amar, Arka Darshan, Arka Gold, Arka Kumkum, Pink Friendship, IIHRG-12, Gladiolus callianthus and Psittacinus hybrid were selected for the experiment. The corms were planted in pots of $12 \mathrm{~cm}$ diameter and 15 $\mathrm{cm}$ depth and $3 \mathrm{~kg}$ capacity, containing potting mixture of soil, vermicompost and sand in the ratio of 2:1:1 (v/v). The layout of the experiment was factorial completely randomized design with three replications and each replication consisted of four pots. The experiment was conducted in a polyhouse of Division of Floriculture and Medicinal Crops, ICAR-Indian Institute of Horticultural Research, Bengaluru, India. The plants were irrigated twice a week through drip irrigation and fertigated at fortnightly interval.

\section{Fungal inoculum}

Two isolates of Fusarium oxysporum f. sp. gladioli i.e. FGS-SOL (ITS- MG650065, TEF- MG652480) and FOG IIHR-1 (ITSMG650067, TEF- MF997484) were used in this study. Pure fungal cultures of these isolates were obtained from Division of Plant Pathology, ICAR-Indian Institute of Horticultural Research, Bengaluru, India. The cultures were grown in Petri plates on potato dextrose agar (PDA) medium at $25^{\circ} \mathrm{C}$. The isolates were mass multiplied on autoclaved sorghum grains (Riaz et al., 2010) and kept for 10-12 days for mycellial growth. Artificial inoculation was carried out as per Negi et al., (1994) with inoculum grown on sorghum 
grains having $3.76 \times 10^{6}$ conidia/ml concentration at the time of planting. The corms were randomly pierced on the surface to facilitate entry of the pathogen. Uninoculated pots were kept as control for each of the genotype.

\section{Disease assessment}

\section{Disease incidence}

The response of all the nine gladiolus genotypes to artificial inoculation was evaluated at 90 days after planting (Elewa et al., 2001). The disease incidence in percent was recorded according to Riaz et al., (2010) and categorization of gladiolus genotypes based on disease incidence percentage was carried out as instructed by Shanmugam et al., (2009) as follows: 0-10 \% = Highly resistant $(\mathrm{HR}) ; 10-25 \%=$ Resistant $(\mathrm{R}) ; 25-50 \%=$ Moderately susceptible (MS); $50-75 \%$ $=$ Susceptible $(\mathrm{S}) ; \quad 75-100 \%=$ Highly susceptible (HS).

Disease incidence $(\%)=$

Number of infected plants

Total number of plants assessed

\section{Area under disease progression curve}

Disease progress curve was obtained from disease incidence percentage observed over the growth period. Disease progress was measured in area under disease progression curve (AUDPC) as follows:

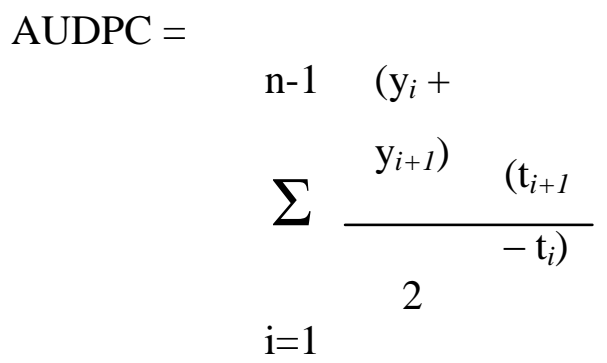

where ' $\mathrm{y}_{i}$ ' is the percentage of diseased plants on $\mathrm{i}^{\text {th }}$ day , $\mathrm{y}_{i+1}$ is the percentage of diseased plants on $\mathrm{i}+1^{\text {th }}$ day, ' $\mathrm{t}_{i+1}-\mathrm{t}_{\mathrm{i}}$ ' is the difference in time between $i^{\text {th }}$ and $i+1^{\text {th }}$ day and ' $n$ ' is the total number of readings (Mohapatra et al., 2008 and Bani et al., 2012). Disease symptoms were assessed at weekly intervals from $3^{\text {rd }}$ leaf stage i.e. 6-7 weeks after planting to flower harvesting stage i.e. 12-13 weeks after planting (Valencia-Botin et al., 2013 and Schwab et al., 2015).

\section{Statistical analysis}

Data for growth and corm yield parameters were statistically analyzed using ANOVA for two factors FCRD with SAS GLM V 9.3 (SAS, 2012) at 1\% level of significance. Dendrograms were constructed using Ward's method (Ward, 1963) based on disease incidence percentage, growth and corm yield parameters in gladiolus genotypes with response to two isolates of Fusarium oxysporum f. sp. gladioli.

\section{Results and Discussion}

\section{Disease incidence}

The inoculated plants showed disease incidence percentage ranging from 0 to 91.67 $\%$ (Table 1). Among the tested gladiolus genotypes, maximum average disease incidence was observed in genotype Pink Friendship (66.67\%) which was moderately susceptible to FGS-SOL isolate and highly susceptible to FOG IIHR-1 isolate. The genotype Psittacinus hybrid was found to be highly resistant to both the isolates of Fusarium oxysporum f. sp. gladioli with no disease incidence. Between the two isolates, average disease incidence percentage was higher in FOG IIHR-1 isolate $(24.07 \%)$ than FGS-SOL isolate $(12.04 \%)$, therefore the former was found to be more virulent than the latter. FOG IIHR-1 isolate resulted in highest 
disease incidence percentage in Pink Friendship (91.67 \%) among all the inoculated gladiolus genotypes.

\section{AUDPC}

The disease progress, in terms of area under disease progression curve (AUDPC) was observed from $3^{\text {rd }}$ leaf stage till flower harvesting. Maximum AUDPC value (2070.91) was recorded in genotype Pink Friendship inoculated with FOG IIHR-1 isolate which was $26.80 \%$ higher than that with FGS-SOL isolate inoculation. No AUDPC value was recorded in the genotype Psittacinus hybrid inoculated with either FGS-SOL or FOG IIHR-1 isolate due to absence of disease incidence within the concerned time period (Fig. 1).

\section{Growth parameters}

\section{Days to sprouting}

Days to sprouting significantly varied among different genotypes and treatments (Table 2). Among the tested genotypes, Arka Amar was the earliest in sprouting (9.39 days) whereas Psittacinus hybrid showed maximum days to sprouting (18.19 days). Days to sprouting was significantly delayed in inoculated plants as compared to the control plants. Days to sprouting was noted to be higher in FOG IIHR-1 isolate infected plants (13.99 days) than FGS-SOL isolate infected plants (13.09 days). The interaction effect between the genotypes and treatments was found to be non-significant.

\section{Plant height}

Maximum plant height was observed in Gladiolus callianthus $(85.69 \mathrm{~cm})$ which was on par with Psittacinus hybrid $(82.26 \mathrm{~cm})$ according to data in Table 2. Plant height was found to be significantly higher in control plants $(78.86 \mathrm{~cm})$ and lowest in plants inoculated with FOG IIHR-1 isolate (64.31 $\mathrm{cm})$. The interaction effect between the genotypes and treatments was found to be non-significant.

\section{Yield parameters}

\section{Number of corms per corm}

Maximum number of corms per corm was observed in Psittacinus hybrid (3.52) which was significantly higher than rest of the genotypes (Table 2). FOG IIHR-1 isolate inoculated plants produced lowest number of corms per corm (1.83) which was significantly lower than control plants (2.40). The interaction between genotypes and treatments was found to be non-significant.

\section{Average weight of corm}

Maximum average weight of corm was obtained in Arka Gold (31.78 g) which was significantly higher than rest of the genotypes (Table 2). FOG IIHR-1 isolate inoculated plants produced significantly low average weight of corm (10.23 g) as compared to control plants $(14.77 \mathrm{~g})$. The interaction effect was found to be highly significant where control plants of Arka Gold produced maximum average weight of corm (36.20 g) and FOG IIHR-1 isolate inoculated plants of Pink Friendship produced lowest average weight of corm $(3.20 \mathrm{~g})$.

\section{Average diameter of corm}

Maximum average diameter of corm was observed in Arka Gold $(4.51 \mathrm{~cm})$ which was significantly higher than rest of the genotypes (Table 2). Average diameter of corm was significantly low in FOG IIHR-1 isolate inoculated plants $(3.01 \mathrm{~cm})$ than in control plants $(3.58 \mathrm{~cm})$. The interaction between genotypes and treatments was found to be non-significant. 
Table.1 Reaction of gladiolus genotypes against isolates of Fusarium oxysporum f. sp. gladioli

\begin{tabular}{|l|l|l|l|l|l|}
\hline \multirow{2}{*}{ Genotypes } & \multicolumn{2}{|c|}{ FGS-SOL isolate } & \multicolumn{2}{c|}{ FOG IIHR-1 isolate } & \multirow{2}{*}{ Genotype Mean } \\
\cline { 2 - 5 } & $\begin{array}{l}\text { Disease } \\
\text { incidence (\%) }\end{array}$ & Category & $\begin{array}{l}\text { Disease } \\
\text { incidence (\%) }\end{array}$ & Category & \\
\hline Arka Amar & 8.33 & HR & 16.67 & R & \\
\hline Arka Gold & 0.00 & HR & 8.33 & HR & 4.50 \\
\hline Arka Darshan & 0.00 & HR & 8.33 & HR & 4.16 \\
\hline Arka Kumkum & 8.33 & HR & 8.33 & HR & 8.33 \\
\hline Arka Aayush & 0.00 & HR & 8.33 & HR & 4.16 \\
\hline IIHRG-12 & 33.33 & MS & 50.00 & S & 41.66 \\
\hline Pink Friendship & 41.67 & MS & 91.67 & HS & 66.67 \\
\hline Psittacinus hybrid & 0.00 & HR & 0.00 & HR & 0.00 \\
\hline Gladiolus callianthus & 16.67 & R & 25.00 & MS & 20.83 \\
\hline Treatment Mean & 12.04 & & 24.07 & & \\
\hline
\end{tabular}

HR= Highly resistant, R= Resistant, MS= Moderately susceptible, $\mathrm{S}=$ Susceptible, HS= Highly susceptible

Table. 2 Growth and corm parameters of gladiolus genotypes inoculated with two isolates of Fusarium oxysporum f. sp. gladioli

\begin{tabular}{|c|c|c|c|c|c|c|c|c|}
\hline \multirow[t]{2}{*}{ Genotypes } & \multicolumn{4}{|c|}{ Days to sprouting } & \multicolumn{4}{|c|}{ Plant height (cm) } \\
\hline & Control & $\begin{array}{l}\text { FGS- } \\
\text { SOL } \\
\text { isolate }\end{array}$ & $\begin{array}{l}\text { FOG } \\
\text { IIHR-1 } \\
\text { isolate }\end{array}$ & Mean & Control & $\begin{array}{l}\text { FGS- } \\
\text { SOL } \\
\text { isolate }\end{array}$ & $\begin{array}{l}\text { FOG } \\
\text { IIHR-1 } \\
\text { isolate }\end{array}$ & Mean \\
\hline Arka Amar & 8.33 & 9.83 & 10.00 & 9.39 & 72.77 & 69.80 & 58.93 & 67.17 \\
\hline Arka Gold & 8.25 & 11.25 & 10.25 & 9.92 & 85.23 & 77.69 & 74.07 & 79.00 \\
\hline Arka Darshan & 13.58 & 15.42 & 13.83 & 14.28 & 78.45 & 66.85 & 61.32 & 68.87 \\
\hline Arka Kumkum & 9.92 & 13.25 & 10.92 & 11.36 & 74.52 & 62.37 & 67.47 & 68.12 \\
\hline Arka Aayush & 12.25 & 14.25 & 13.00 & 13.17 & 70.52 & 62.97 & 57.82 & 63.77 \\
\hline IIHRG-12 & 10.17 & 12.58 & 12.33 & 11.69 & 80.11 & 71.13 & 62.59 & 71.28 \\
\hline Pink Friendship & 10.00 & 11.75 & 12.00 & 11.25 & 69.49 & 54.92 & 45.77 & 56.73 \\
\hline Psittacinus hybrid & 17.92 & 18.83 & 17.83 & 18.19 & 88.83 & 82.23 & 75.67 & 82.26 \\
\hline G. callianthus & 15.25 & 18.33 & $\mid 18.00$ & 17.19 & 89.82 & 87.05 & 80.18 & 85.69 \\
\hline \multirow[t]{2}{*}{ Mean } & 11.73 & 13.09 & 13.99 & & 78.86 & 71.13 & 64.31 & \\
\hline & Genotypes & \multicolumn{2}{|c|}{ Treatments } & $\begin{array}{c}\text { Genotypes } \times \\
\text { treatments }\end{array}$ & Genotypes & \multicolumn{2}{|c|}{ Treatments } & $\begin{array}{c}\text { Genotypes } \times \\
\text { treatments }\end{array}$ \\
\hline SEm \pm & 0.45 & & 0.26 & 0.77 & 2.43 & & 1.40 & 4.21 \\
\hline CD at $1 \%$ & 1.19 & & 0.12 & 2.07 & 6.49 & & 3.41 & 11.24 \\
\hline
\end{tabular}


Fig.1 Area under disease progression curve (AUDPC) of gladiolous genotypes upon inoculation with FGS-SOL isolate and FOG IIHR-1 isolate of Fusarium oxysporum f. sp. gladioli

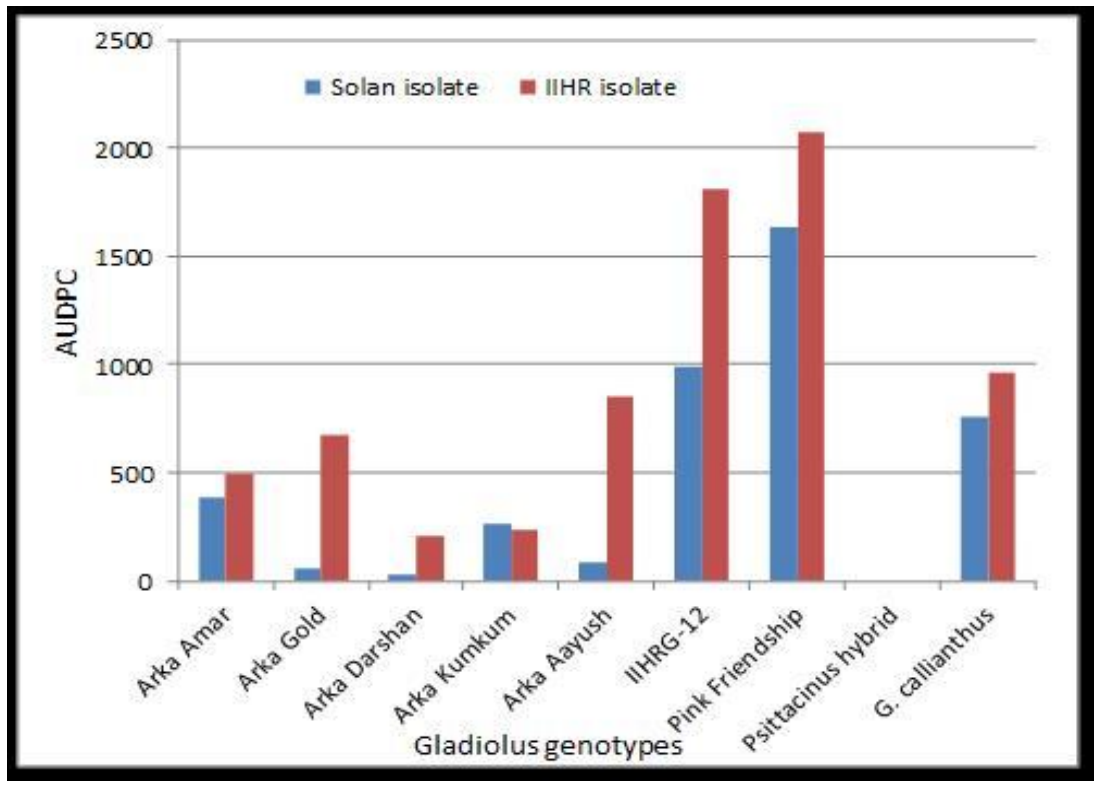

Fig.2 Dendrogram of gladiolus genotypes against FGS-SOL isolate

Arka Amar
Arka Darshan
Arka Aayush
Arka Kumkum
IIHRG-12
Pink Friendship
Arka Gold
Psittacinus hybrid
G. callianthus

Fig.3 Dendrogram of gladiolus genotypes against FOG IIHR-1 isolate

Arka Amar

Arka Kumkum

Arka Darshan

Arka Aayush

IIHRG-12

Pink Friendship

Arka Gold

Psittacinus hybrid

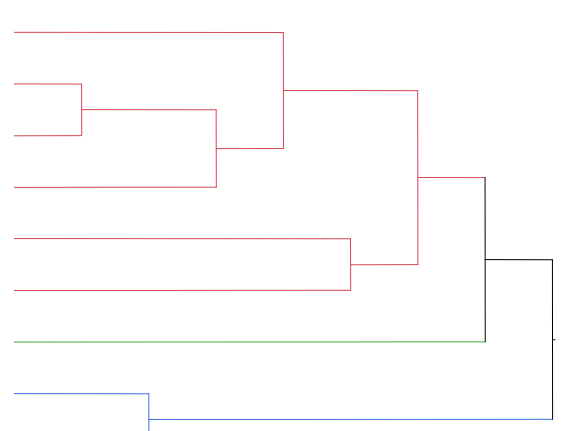

G. callianthus 
Table.2 Continued

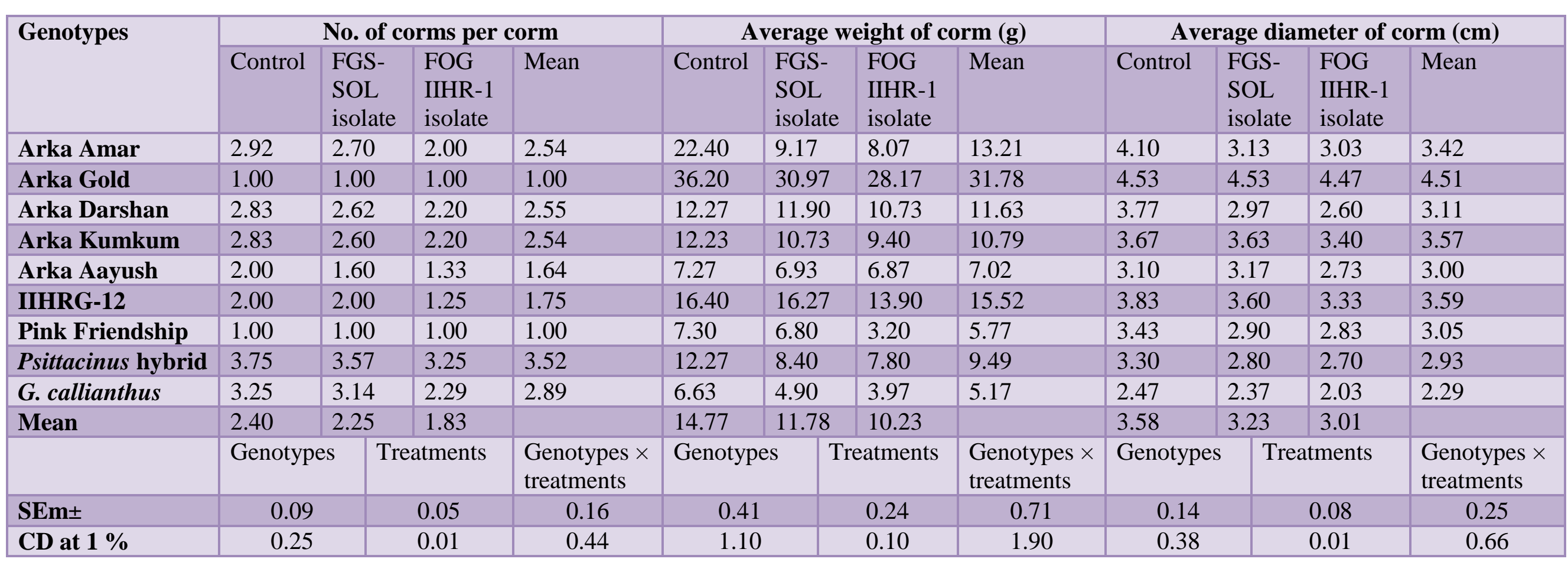


Table.3 Genetic distance among different gladiolus genotypes with respect to FGS-SOL isolate

\begin{tabular}{|l|l|l|l|l|l|l|l|l|l|}
\hline & $\begin{array}{l}\text { Arka } \\
\text { Amar }\end{array}$ & $\begin{array}{l}\text { Arka } \\
\text { Gold }\end{array}$ & $\begin{array}{l}\text { Arka } \\
\text { Darshan }\end{array}$ & $\begin{array}{l}\text { Arka } \\
\text { Kumkum }\end{array}$ & $\begin{array}{l}\text { Arka } \\
\text { Aayush }\end{array}$ & $\begin{array}{l}\text { IIHRG- } \\
\text { 12 }\end{array}$ & $\begin{array}{l}\text { Pink } \\
\text { Friendship }\end{array}$ & $\begin{array}{l}\text { Psittacinus } \\
\text { hybrid }\end{array}$ & $\begin{array}{l}\text { Gladiolus } \\
\text { callianthus }\end{array}$ \\
\hline Arka Amar & 0.00 & 4.15 & 1.95 & 1.56 & 2.08 & 2.31 & 3.28 & 3.38 & 3.56 \\
\hline Arka Gold & 4.15 & 0.00 & 4.26 & 3.82 & 4.17 & 3.46 & 5.31 & 5.48 & 5.96 \\
\hline Arka Darshan & 1.95 & 4.26 & 0.00 & 1.45 & 1.43 & 2.71 & 3.67 & 2.20 & 2.82 \\
\hline Arka Kumkum & 1.56 & 3.82 & 1.45 & 0.00 & 1.54 & 2.06 & 3.17 & 3.21 & 3.71 \\
\hline Arka Aayush & 2.08 & 4.17 & 1.43 & 1.54 & 0.00 & 2.74 & 3.00 & 3.29 & 3.60 \\
\hline IIHRG-12 & 2.31 & 3.46 & 2.71 & 2.06 & 2.74 & 0.00 & 2.60 & 3.92 & 3.81 \\
\hline Pink Friendship & 3.28 & 5.31 & 3.67 & 3.17 & 3.00 & 2.60 & 0.00 & 5.24 & 4.82 \\
\hline Psittacinus hybrid & 3.38 & 5.48 & 2.20 & 3.21 & 3.29 & 3.92 & 5.24 & 0.00 & 1.51 \\
\hline $\begin{array}{l}\text { Gladiolus } \\
\text { callianthus }\end{array}$ & 3.56 & 5.96 & 2.82 & 3.71 & 3.60 & 3.81 & 4.82 & 1.51 & 0.00 \\
\hline
\end{tabular}

Table.4 Genetic distance among different gladiolus genotypes with respect to FGS-IIHR isolate

\begin{tabular}{|l|r|r|r|r|r|r|r|r|r|}
\hline & $\begin{array}{l}\text { Arka } \\
\text { Amar }\end{array}$ & $\begin{array}{l}\text { Arka } \\
\text { Gold }\end{array}$ & $\begin{array}{l}\text { Arka } \\
\text { Darshan }\end{array}$ & $\begin{array}{l}\text { Arka } \\
\text { Kumkum }\end{array}$ & $\begin{array}{l}\text { Arka } \\
\text { Aayush }\end{array}$ & $\begin{array}{l}\text { IIHRG- } \\
\text { 12 }\end{array}$ & $\begin{array}{l}\text { Pink } \\
\text { Friendship }\end{array}$ & $\begin{array}{l}\text { Psittacinus } \\
\text { hybrid }\end{array}$ & $\begin{array}{l}\text { Gladiolus } \\
\text { callianthus }\end{array}$ \\
\hline Arka Amar & 0.00 & 3.95 & 1.54 & 1.10 & 1.46 & 1.96 & 3.29 & 3.56 & 3.72 \\
\hline Arka Gold & 3.95 & 0.00 & 4.29 & 3.43 & 4.24 & 3.20 & 5.69 & 5.45 & 5.80 \\
\hline Arka Darshan & 1.54 & 4.29 & 0.00 & 1.64 & 1.35 & 2.29 & 3.78 & 2.41 & 2.63 \\
\hline Arka Kumkum & 1.10 & 3.43 & 1.64 & 0.00 & 1.93 & 2.11 & 4.04 & 3.02 & 3.46 \\
\hline Arka Aayush & 1.46 & 4.24 & 1.35 & 1.93 & 0.00 & 1.99 & 3.15 & 3.48 & 3.22 \\
\hline IIHRG-12 & 1.96 & 3.20 & 2.29 & 2.11 & 1.99 & 0.00 & 2.69 & 4.06 & 3.79 \\
\hline $\begin{array}{l}\text { Pink } \\
\text { Friendship }\end{array}$ & 3.29 & 5.69 & 3.78 & 4.04 & 3.15 & 2.69 & 0.00 & 5.56 & 4.90 \\
\hline $\begin{array}{l}\text { Psittacinus } \\
\text { hybrid }\end{array}$ & 3.56 & 5.45 & 2.41 & 3.02 & 3.48 & 4.06 & 5.56 & 0.00 & \\
\hline $\begin{array}{l}\text { Gladiolus } \\
\text { callianthus }\end{array}$ & 3.72 & 5.80 & 2.63 & 3.46 & 3.22 & 3.79 & 4.90 & 1.94 & \\
\hline
\end{tabular}




\section{Cluster analysis}

A dendrogram was constructed based on disease reaction, growth and corm yield characters of gladiolus genotypes inoculated with FGS-SOL isolate (Fig.2). The dendrogram represented three clusters. Genotypes Arka Darshan and Arka Aayush showed highest similarity for disease incidence percentage, growth and corm yield with genetic distance of 1.43 and were clustered in one group. Highest genetic similarity was also shown by genotypes Psittacinus hybrid and Gladiolus callianthus with genetic distance of 1.51 which formed another cluster.

Another dendrogram was created for different gladiolus genotypes inoculated with FOG IIHR-1 isolate based on disease incidence, growth and corm yield parameters (Fig. 3). It was observed that the gladiolus genotypes were grouped into three clusters. Genotypes Arka Amar and Arka Kumkum were found to be grouped into one cluster having highest genetic similarity for the evaluated parameters with a genetic distance of 1.10 followed by genotypes Arka Darshan and Arka Aayush belonging to the same cluster with a genetic distance of 1.35 (Table 3 and 4).

\section{Disease incidence}

The response of gladiolus genotypes to inoculation of $F$. oxysporum f. sp. gladioli varied significantly with respect to its two geographically different isolates. The genotype Psittacinus hybrid showed no disease incidence in response to FGS-SOL isolate and FOG IIHR-1 isolate inoculation suggesting that it was highly resistant to both the isolates. Similar result was also obtained by Taj et al., (2016) where they reported that Psittacinus hybrid showed resistance to different isolates of $F$. oxysporum f. $\mathrm{sp}$. gladioli with no disease incidence. The genotype Pink Friendship scored highest average disease incidence percentage i.e. $66.67 \%$ among all the inoculated genotypes. Riaz et al., (2007) and Raj and Kumar (2009) in their separate studies observed that susceptible hybrid of gladiolus scored disease incidence percentage of $57 \%$ and $45 \%$ respectively, against the inoculation with geographically different isolates of $F$. oxysporum f. sp. gladioli. Similarly, Pink Friendship was also found to be susceptible to Fusarium wilt disease by Shanmugan et al., (2009) and Kumari et al., (2015). Plants inoculated with FOG IIHR-1 isolate scored higher disease incidence percentage as compared to FGS-SOL isolate. Similar disparity in the pathogenic ability of geographically different isolate of $F$. oxysporum f. sp. gladioli was also observed by Riaz et al., (2007). The variation in the reaction of gladiolus genotypes to inoculation may be attributed to the difference in their genetic constitution (Saha et al., 2016) and the pathogenic ability of the isolates of $F$. oxysporum f. sp. gladioli (Elewa et al., 2001).

\section{Cluster analysis}

Cluster analysis grouped genotypes with high genetic similarity in the same cluster for resistance reaction against the two isolates of F. oxysporum f. sp. gladioli, growth and corm yield parameters. Cluster analysis was used to analyze the effect of different pathotypes of Verticillium dahlia on various olive cultivars (Calderón et al., 2014) and assessment of som (Persea bombycina) for resistance against Phyllactinia leaf spot disease (Chattopadhyay et al., 2014).

\section{AUDPC}

Area under disease progression curve varied among the gladiolus genotypes inoculated by two different isolates of Fusarium oxysporum f.sp. gladioli. Disease scoring with 
the help of disease incidence may not be sufficient for evaluating quantitative resistance against Fusarium wilt disease due to gradient symptoms of severity (Teng and James, 2002). AUDPC takes into account disease severity in a timeline, while disease incidence percentage are calculated based on data collected at a single point of time. Since AUDPC embodies the interaction of host, pathogen and environmental effects during the disease development, assessment of AUDPC would be crucial for evaluation of disease resistance in plants (Chattopadhyay et al., 2014). Pouralibaba et al., (2015) claimed that plants with lower AUDPC shows delayed symptoms and suffer less during the infection and that AUDPC is informative in assessing the level of resistance in plants against various diseases (Meles et al., 2004). Use of AUDPC as a measurement of quantitative disease resistance against soil borne diseases caused by Fusarium spp. has been carried out by Perchepied and Pitrat (2004) for Fusarium oxysporum f. sp.melonis, Altinok and Can (2010) for $F$. oxysporum f.sp. melongenae, McPhee et al., (2012) for F. oxysporum f.sp. pisi and Pouralibaba et al., (2015) for $F$. oxysporum f.sp. lentis.

\section{Growth and corm yield parameters}

Fusarium wilt disease in gladiolus genotypes has severely affected growth, and corm yield attributes. Days to sprouting was delayed along with drastic reduction in plant height, number of corms per corm, average size of corm and average weight of corm. Raj and Kumar (2009) reported significant reduction in plant height, corm size and corm weight due to Fusarium wilt in gladiolus. Riaz et al., (2010) also concluded that $F$. oxysporum f. sp. gladioli severely affected days to sprouting, corm diameter and corm weight in susceptible varieties of gladiolus. Yasmin and Ali (2016) also stated that due to Fusarium wilt disease in gladiolus, days to sprouting was delayed whereas plant height, number of corms per corm, corm weight, corm diameter were considerably reduced.

The study was conducted with the aim of observing resistance reaction of gladiolus genotypes against Fusarium wilt disease. Based on results of disease incidence, cluster analysis and AUDPC it was found that Psittacinus hybrid and Pink Friendship were the resistant and susceptible genotypes, respectively. Fusarium oxysporum f. sp. gladioli FOG IIHR-1 isolate was found to be more virulent than FGS-SOL isolate. This information can be utilized in studying molecular interaction between the virulent isolate of Fusarium oxysporum f. sp. gladioli with resistant and susceptible gladiolus genotypes for identification of resistance genes. The genotypes showing resistance to Fusarium wilt disease can also be used in breeding programs for development of resistant cultivars.

\section{References}

Altınok, H.H. and Can, C. 2010. Characterization of Fusarium oxysporum f. sp. melongenae isolates from eggplant in Turkey by pathogenicity, VCG and RAPD analysis. Phytoparasitica, 38(2): 149-157.

Anonymous. 2016. Horticulture crops estimates for the year 2015-16. National Horticulture Board, Haryana. Ministry of Agriculture and Farmer's Welfare, Government of India.

Bani, M., Rubiales, D. and Rispail, N. 2012. A detailed evaluation method to identify sources of quantitative resistance to Fusarium oxysporum f. sp. pisi race 2 within a Pisum spp. germplasm collection. Plant Pathology, 61(3): 532-542.

Calderón, R., Lucena, C., Trapero-Casas, J.L., Zarco-Tejada, P.J. and Navas-Cortés, J.A. 2014. Soil temperature determines the reaction of olive cultivars to Verticillium dahliae pathotypes. PloS one, 9(10): e110664. 
Cantor, M. and Tolety, J. 2011. Gladiolus. In: wild crop relatives: genomic and breeding resources. Chittaranjan Kole (Ed) Springer Berlin Heidelberg. pp. 133-159.

Chattopadhyay, S., Sangma, C.D., Tikader, A., Rajan, R.K. and Bindroo, B.B. 2014. Assessment of som (Persea bombycina) clones for resistance against Phyllosticta persae. Tropical Plant Pathology, 39(3): 259-264.

Dwivedi, N., Deen, B., Kumar, A., Sharma, M.M. and Jaiswal, A.K. 2018. Standardization of Vase Solutions for Maximum Buds Opening and Longer Vase-Life of Gladiolus Flower cv. Nova Lux. Int. J. Curr. Microbiol. App. Sci, 7(3): 3145-3150.

Elewa, I.S., Hilal, A.A., Hassan, S.E. and Abd ElMalak, S. 2001. Studies on Fusarium Disease (Fusarium oxysporum Schlecht. f. sp. gladioli (Massey) Synd. and Hans. of gladiolus. Egyptian J. Phytopatho. 22(2): 8395.

Kakade, D.S., Jadhav, S.B. and Katwate, S.M. 2016. Management of Fusarium wilt in Gladiolus. Int. J. Pure App. Biosci, 4(5): 127-132.

Khan, M. and Mustafa, U. 2005. Corm rot and yellows of gladiolus and its biomanagement. Phytopathologia Mediterranea, 44(2): 208215.

Kumari, P., Manjunatha Rao, T., Dhananjaya, M.V., Kumar, R. and Venugopalan, R. 2015. Morphological characterizations of gladiolus (Gladiolus $\mathrm{x}$ hybridus Hort.) for resistance to Fusarium wilt disease. The Bioscan, 10(3): 1419-1422.

Lakshman, D.K., Pandey, R., Kamo, K., Bauchan, G. and Mitra, A. 2012. Genetic transformation of Fusarium oxysporum f. sp. gladioli with Agrobacterium to study pathogenesis in Gladiolus. European journal of plant pathology, 133(3): 729-738.

Manning, J. and Goldblatt, P. 2008. The Iris family: Natural history \& classification. Portland, Oregon, Timber Press. pp. 138142.

Massey, L.M. 1926. Fusarium rot of gladiolus corms. Phytopathology, 52: 567-572.

Mc Phee, K.E., Inglis, D.A., Gundersen, B. and Coyne, C.J. 2012. Mapping QTL for Fusarium wilt Race 2 partial resistance in pea (Pisum sativum). Plant breeding, 131(2):300-306.

Meles, K., Hulluka, M. and Abang, M.M. 2004. Phenotypic diversity in Rhynchosporium secalis from Ethiopia and host response to barley scald. Plant Pathology Journal. 3:2634.

Mohapatra, N.K., Mukherjee, A.K., Suriya Rao, A.V. and Nayak, P. 2008. Disease progress curves in the rice blast pathosystem compared with the logistic and Gompertz models. Journal of Agricultural and Biological Science, 3(1): 28-37.

Mundt, C.C. 2014. Durable resistance: a key to sustainable management of pathogens and pests. Infection, Genetics and Evolution, 27: 446-455.

Negi, S.S., Raghava, S.P.S., Chacko, C.I. and Rao, T.M. 1994. Breeding for quality and resistance to Fusarial wilt in gladiolus. In: Horticulture- New technologies and Applications. Prakash $\mathrm{J}$ and Pierik RLM (Eds.). Proceedings of the International Seminar on New Frontiers in Horticulture. pp 21-25.

\section{How to cite this article:}

Raimani Hembrom, T. Manjunatha Rao, S. Sriram, Rajiv Kumar, R. Venugopalan and Dhananjaya, M.V. 2019. Evaluation of Gladiolus Genotypes for Resistance to Different Isolates of Fusarium oxysporum f. sp. gladioli. Int.J.Curr.Microbiol.App.Sci. 8(06): 2811-2821. doi: https://doi.org/10.20546/ijcmas.2019.806.339 